Covered in: ERIH PLUS, CEEOL, Index Copernicus, CrossRef, CrossCheck, J-Gate, Google Scholar, Ideas RePeC, Econpapers, Socionet, KVK, WorldCat.

2020, Volume 8, Issue 1, pages: 01- 07| doi: 10.18662/lumenphs/8.1/31

\section{Retraumatized: \\ Covid-19, the \\ Specter of \\ HIV/AIDS, and \\ Reorienting \\ Responsability}

\section{Sana LOUE', Erin Gentry LAMB2}

${ }^{1}$ Ph.D., M.P.H., M.S.S.A., M.A., LISW-S, a professor at Case Western Reserve University School of Medicine in the Departments of Bioethics and Psychiatry and in the Center for Global Health, has conducted HIV behavioral research for close to 20 years and has been active in promoting the establishment of harm reduction programs, E-mail:

sx154@,case.edu

${ }^{2}$ Ph.D., is the faculty lead of the Humanities Pathway and Visiting Associate Professor of Bioethics and Medical Humanities at the Case Western Reserve University School of Medicine
Abstract: We are assaulted each day with news of more COVID-19 deaths, more infections, new complications. Loved ones die unable to say goodbye, their bodies waiting for burial in refrigerated trucks as the morgues are full. In the United States, our federal government's indifference- symbolized by our president's monthslong refusal to wear a mask-is amplified through White House news briefings that make clear that the deaths due to COVID-19 are merely the cost of doing business (Walters \& Graham, 2020). The missteps of the Center for Disease Control (CDC) diminished our country's readiness to address this unseen onslaught. Initial characterizations of the coronavirus as only lethal for old people contributed to sluggish reactions among governments and a false sense of security for those not old (Fraser et al., 2020). Religious leaders suggest that those who become infected are less than morally worthy (Merritt, 2020). And the brunt of the disease is falling on those who most often experience the injustice of and marginalization by our society-persons of color, homeless, incarcerated. Some of us have been here before.

Keywords: HIV/AIDS; COVID-19; responsibility.

How to cite: Loue, S., \& Lamb, E, G. (2020). Retraumatized: Covid-19, the Specter of HIV/AIDS, and Reorienting Responsability. Logos Universality Mentality Education Novelty: Philosophy \& Humanistic Sciences, 8(1), 01-07. doi: 10.18662/lumenphs/8.1/31 


\section{Retraumatized: Covid-19, the Specter of HIV-AIDS, and Reorienting Responsability}

We are assaulted each day with news of more COVID-19 deaths, more infections, new complications. Loved ones die unable to say goodbye, their bodies waiting for burial in refrigerated trucks as the morgues are full. In the United States, our federal government's indifference-symbolized by our president's months-long refusal to wear a mask-is amplified through White House news briefings that make clear that the deaths due to COVID19 are merely the cost of doing business (Walters \& Graham, 2020). The missteps of the Center for Disease Control (CDC) diminished our country's readiness to address this unseen onslaught. Initial characterizations of the coronavirus as only lethal for old people contributed to sluggish reactions among governments and a false sense of security for those not old (Fraser et al., 2020). Religious leaders suggest that those who become infected are less than morally worthy (Merritt, 2020). And the brunt of the disease is falling on those who most often experience the injustice of and marginalization by our society-persons of color, homeless, incarcerated. Some of us have been here before.

Many have compared our present moment to the 1918 flu pandemic, but there is another, still ongoing, pandemic in our world that many of us have known intimately: HIV/AIDS. Every ring of the telephone, every scream of an ambulance siren, brings back memories of the early years of the HIV/AIDS pandemic, when there was no treatment, when a diagnosis meant almost certain death and the only question was how soon and from what related complication. Just as with COVID-19 now, we had no sense of when "it" would end-the spread of the disease, the anxiety that came with being ill and not knowing when or how one's life would end, the exhaustion of caring for those we loved, the funerals and memorial services. People died, alone in their hospital beds, without the comfort of their loved ones, as long-estranged family members who had legal priority in making healthcare decisions for their sons and brothers forbade same-sex partners from entering hospital rooms (Paul, 2020). We searched for funeral homes and cemeteries willing to accept the bodies of our friends and colleagues; many did not, fearful of this yet seemingly uncontrollable disease (Bass, 1987). The American government was indifferent; the Reagan administration failed to even voice the name of the infection for close to two years following the initial reports of this then-new clinical syndrome (Boffey, 1985). The CDC's initial characterization of HIV risk by group-the " $4 \mathrm{H}$ club" of Haitians, 
hemophiliacs, homosexuals, and heroin users - rather than by behavior led to a false sense of security among individuals who did not define themselves within any of these groups, and provided fodder for religious groups too eager, too willing to cast moral blame on those who became ill (Lederer, 2000). To this day, minority communities remain disproportionately impacted by HIV/AIDS.

The similarities do not end there. The White House has proclaimed that the COVID-19 pandemic is attributable to a Chinese laboratory (Singh, Davidson, \& Borger, 2020); AIDS conspiracy theories, too, cast blame on laboratories for the origin of the illness (Ross, Essien, \& Torres 2006). Behaviors rightly or wrongly believed to be associated with transmission have been criminalized, such as spitting in the case of COVID-19 (Tarinelli, 2020) and in the time of HIV/AIDS (Satta, 2019). The finding that individuals may be infected with COVID-19 but asymptomatic has led to calls to for both voluntary self-quarantine and mandated quarantine (Anon., 2020). HIV/AIDS similarly brought forth calls for the mandatory quarantine of all infected persons (National Research Council, 1993; Hirth \& Grogan, 1988). Then, as now, we see the proliferation of fraudulent treatments and cures from hucksters that prey on individuals' fear and desperation. Similar human rights and legal issues are of concern now as then: the reach of the government in its efforts to protect the public health and the balance of such efforts with individual freedoms; the limits of privacy and confidentiality; the potential liability of healthcare institutions due to inadequate protective supplies and mechanisms for its employees and patients.

The déjà vu evoked by these parallels has been traumatic for many of us these past months, especially as we reflect on how prevalent HIV remains several decades into the pandemic. With both pandemics, the heavier disease and death burden on already marginalized communities has led to calls to focus on social determinants of health-food deserts, lack of healthcare insurance, poverty, lack of access to care. This focus, however, belies the true cause underlying the disparities that we see-structural violence, established and maintained through legislation and policy designed to preserve privilege (Murray, 2014). These many parallels-holding true over the past four decades (and beyond) - expose the root of such structural violence: a fundamental ethos of selfishness that naturalizes the prioritization of self-interests and the existence of inequality (Krugman, 2020).

What we have now in the U.S, unfortunately, is nothing short of terroristic displays by privileged persons carrying assault weapons-cheered 
on by those privy to even greater privilege and less risk-demanding their right to do as they please without regard to the impact on those around them or to the welfare of those health care workers who would be tasked with their care should they become infected due to their own recklessness. The words of the American Medical Association, the appeals of health care workers on social media and to the press, the knowledge that even those in the protected bubble of the White House now test positive for COVID19-all have failed to move many of our legislators and a large proportion of our countrypersons from their complacency and sense of entitlement. Maskwearing has been framed as a statement of political affiliation rather than a means by which each of us can do our part to reduce contagion. What is needed now is nothing short of an equal and opposite response to the highly publicized COVID-19-related demands for individual (or national) exceptionalism, for rights without responsibility.

On this score, we have much we can learn from the parallels between COVID-19 and HIV/AIDS. Ultimately, governments on all continents came to recognize the need to engage in collaborative research and prevention efforts if the spread of HIV was ever to be lessened. Additionally and importantly, governments emphasized the need for each individual to accept responsibility for their own health and their behavior towards others, e.g., to refrain from unprotected sexual relations, from sharing injection equipment. Uganda, as an example, embarked on a widespread, sustained campaign to encourage the use of condoms (Cohen, 2003; Uganda AIDS Commission, 2017).

There are now significant global collaborations seeking to identify effective treatments and preventive vaccines to limit the sequelae and transmission of COVID-19. Sexologists and public health officials suggest we can look to the last forty years of promoting condom use for best practices in encouraging people to wear unpleasurable protective barriers to prevent viral contagion - a measure undertaken to protect both oneself and one's partner (Klass, 2020).

However, what remains absent in the U.S. and many other countries-where mandates to physically distance or to wear a mask may be nonexistent, disregarded, or unenforced-is a similar emphasis on personal responsibility towards others. The populations of Japan, South Korea, mainland China and some other Asian nations are notable for their efforts to protect each other through physical distancing and the use of masks in the "spirit of solidarity" (Wong, 2020). In countries such as the U.S., it is easy to point the finger at governments for failing to issue mandates, or failing to offer and model consistent messaging on the value of mask-wearing, and 
Retraumatized: Covid-19, the Specter of HIV/AIDS, and Reorienting ... Sana LOUE, Erin Gentry LAMB

these are indeed culprits of COVID-19 spread. Ultimately, however, it is the entire ethos of many countries, and the citizens within them, that need our scrutiny. We need to translate the indifference of contagious disease to class, racial, and other fault lines- "the virus doesn't care who you are or what you believe" - into recognition of our interdependence and a prioritizing of the collective rather than the individual good. This will involve recognizing our collective responsibility for living situations like slums and homeless shelters that may render responsible personal behaviors ineffective, and refocusing media attention from our political debacles back to the public interest, illustrating the tethers of influence and interdependence that connect one person's pandemic experience to another's. The trauma wrought by COVID-19 need not continue. As with HIV, it may ultimately be abated through the development of effective treatments if not a vaccine. But like HIV, the human suffering associated with COVID-19 can be reduced and, indeed, eliminated if every individual accepts responsibility to do their part to protect others-physically distance and wear a mask.

\section{References}

Anon. (2020). Couple sues cruise line over handling of coronavirus outbreak: "We would have gotten off that ship." CBS News, 10 March 2020.

https://www.cbsnews.com/news/coronavirus-quarantined-cruise-grandprincess-passengers-lawsuit-exposed-people-covid-19/

Bass, S. L. (1987, November 15). Funeral homes accused of bias on AIDS. The New York Times. https://www.nytimes.com/1987/11/15/nyregion/funeralhomes-accused-of-bias-on-aids.html

Boffey, P. (1985, September 18). Reagan defends financing for AIDS. The New York Times. https://www.nytimes.com/1985/09/18/us/reagan-defendsfinancing-for-aids.html

Cohen, S. A. (2003). Beyond slogans: Lessons from Uganda's experience with ABC and HIV/AIDS. Guttmacher Policy Review, 6(5). https://www.guttmacher.org/gpr/2003/12/beyond-slogans-lessonsugandas-experience-abc-and-hiv/aids\#

Fraser, S., Lagacé, M., Bongué, B., Ndeye, N., Guyot, J., Bechard, L., Garcia, L.,... \& Tougas, F. (2020). Ageism and COVID-19: What does our society's response say about us?. Age and Ageing, afaa097. https://doi.org/10.1093/ageing/afaa097

Hirth, D., \& Grogan, J. (1988, Apr. 8). AIDS quarantine is endorsed law would target those who deliberately spread the disease. The SunSentinel. https://www.sun-sentinel.com/news/fl-xpm-1988-04-08-8801220655story.html 
Klass, P. (2020, July 21). To get people to wear masks, look to seatbelts, helmets and condoms. The New York Times.

https://www.nytimes.com/2020/07/21/well/ family/masks-condomsseatbelts-helmets.html

Krugman, P. (2020, July 27). The cult of selfishness is killing America. The New York Times. https://www.nytimes.com/2020/07/27/opinion/usrepublicans-coronavirus.html

Lederer, B. (2000, December 01). The 4-H club. Poz: https://www.poz.com/article/4h-club

Merritt, J. (2020, April 24). Some of the most visible Christians in America are failing the coronavirus test. The Atlantic. https://www.theatlantic.com/ideas/ archive/2020/04/christian-crueltyface-covid-19/610477/

Murray, Y. M. (2014). Law and the possibilities of peace. Seattle Journal for Social Justice, 13(2.3), 251-286. https://digitalcommons.law.seattleu.edu/sjsj/vol13/iss $2 / 3$

National Research Council (US). (1993). Panel on Monitoring the Social Impact of the AIDS Epidemic. In A. R. Jonsen \& I. Stryker J. (Eds.). (1993), The social impact of AIDS in the United States. National Academies Press.

Paul, C. (2020, April 26). For those who lived through the HIV/AIDS epidemic in Seattle, the coronavirus pandemic brings echoes of past trauma. The Seattle Times. https://www.seattletimes.com/life/for-those-who-lived-throughthe-hiv-aids-epidemic-in-seattle-the-coronavirus-pandemic-brings-echoesof-past-trauma/

Ross, M. W., Essien, E. J., \& Torres, I. (2006). Conspiracy beliefs about the origin of HIV/AIDS in four racial/ethnic groups. Journal of Acquired Immune Deficiency Syndromes (1999), 41(3), 342-344. https://doi.org/10.1097/01.qai.0000209897.59384.52

Tarinelli, R. (2020, April 17). 'Heightened anxiety': Buffalo woman faces federal charges in COVID-19 spitting case. New York Law Journal. https://www.law.com/newyorklawjournal/2020/04/17/heightenedanxiety-buffalo-woman-faces-federal-charges-in-covid-19-spitting-case/

Satta, M. (2019, February 25). Spitting at science: The unjustified criminalization of spitting while HIV-positive. Bill of Health [blog post]. https://blog.petrieflom.law.harvard.edu/2019/02/25/spitting-at-sciencethe-unjustified-criminalization-of-spitting-while-hiv-positive/

Singh, M., Davidson, H., \& Borger, J. (2020, April 30). Trump claims to have evidence coronavirus started in Chinese lab but offers no details. The Guardian. https://www.theguardian.com/us-news/2020/apr/30/donaldtrump-coronavirus-chinese-lab-claim 
Retraumatized: Covid-19, the Specter of HIV/AIDS, and Reorienting ... Sana LOUE, Erin Gentry LAMB

Uganda AIDS Commission. (2017). Uganda HIV/AIDS country progress report July 2016-June 2017. https://www.unaids.org/sites/default/files/country/documents/UGA 20 18 countryreport.pdf

Walters, J., \& Graham, B.A. (2020, July 11). Donald Trump wears mask in public for first time during Covid-19 pandemic. The Guardian.

https://www.theguardian.com/ us-news/2020/jul/11/donald-trump-facemask-covid-19-coronavirus-hospital-visit

Wong, T. (2020, May 12). Coronavirus: Why some countries wear face masks and others don't. BBC. https://www.bbc.com/news/world-52015486 